\title{
Nitrogen Oxides in Early Earth's Atmosphere as Electron Acceptors for Life's Emergence
}

\author{
Michael L. Wong,, Benjamin D. Charnay, ${ }^{2,3}$ Peter Gao, Yuk L. Yung,, ${ }^{1,5}$ and Michael J. Russell ${ }^{5}$
}

\begin{abstract}
We quantify the amount of nitrogen oxides (NOx) produced through lightning and photochemical processes in the Hadean atmosphere to be available in the Hadean ocean for the emergence of life. Atmospherically generated nitrate $\left(\mathrm{NO}_{3}^{-}\right)$and nitrite $\left(\mathrm{NO}_{2}^{-}\right)$are the most attractive high-potential electron acceptors for pulling and enabling crucial redox reactions of autotrophic metabolic pathways at submarine alkaline hydrothermal vents. The Hadean atmosphere, dominated by $\mathrm{CO}_{2}$ and $\mathrm{N}_{2}$, will produce nitric oxide (NO) when shocked by lightning. Photochemical reactions involving $\mathrm{NO}$ and $\mathrm{H}_{2} \mathrm{O}$ vapor will then produce acids such as $\mathrm{HNO}, \mathrm{HNO}_{2}$, $\mathrm{HNO}_{3}$, and $\mathrm{HO}_{2} \mathrm{NO}_{2}$ that rain into the ocean. There, they dissociate into or react to form nitrate and nitrite. We present new calculations based on a novel combination of early-Earth global climate model and photochemical modeling, and we predict the flux of NOx to the Hadean ocean. In our 0.1-, 1-, and 10-bar $\mathrm{pCO}_{2}$ models, we calculate the NOx delivery to be $2.4 \times 10^{5}, 6.5 \times 10^{8}$, and $1.9 \times 10^{8}$ molecules $\mathrm{cm}^{-2} \mathrm{~s}^{-1}$. After only tens of thousands to tens of millions of years, these NOx fluxes are expected to produce sufficient (micromolar) ocean concentrations of high-potential electron acceptors for the emergence of life. Key Words: Nitrogen oxidesNitrate-Nitrite_Photochemistry—Lightning-Emergence of life. Astrobiology 17, 975-983.
\end{abstract}

\section{Introduction}

$\mathbf{N}$ ITROGEN OXIDES (NOX) - formed by lightning discharges and photochemistry in the Hadean atmosphere and rained out into the all-enveloping Hadean ocean-may have played a vital role in the emergence and early evolution of life on Earth (Mancinelli and McKay, 1988). In particular, the high-potential electron acceptors nitrate $\left(\mathrm{NO}_{3}{ }^{-}\right)$and nitrite $\left(\mathrm{NO}_{2}^{-}\right)$could conceivably have initiated the first metabolic pathway through the oxidation of hydrothermal $\mathrm{CH}_{4}$ and the concomitant hydrogenation of $\mathrm{CO}_{2}$ at ancient submarine alkaline hydrothermal vents (Ducluzeau et al., 2009; Nitschke and Russell, 2013; Shibuya et al., 2016).

In contrast to the renowned magma-driven "black smoker" springs $\left(350-400^{\circ} \mathrm{C}, \mathrm{pH} \sim 3\right)$, Hadean alkaline hydrothermal systems would have been powered by the geothermal gradient, augmented by exothermic serpentinization of the mainly peridotitic crust (Table 1). Their effluents would have been not only moderately hot $\left(\leq 92^{\circ} \mathrm{C}\right)$ but also alkaline $(\mathrm{pH}$ $\sim 11)$. These fluids would have reacted with the then acidic ocean to produce porous submarine hydrothermal mounds (Russell et al., 2010).
The present-day hydrothermal vents at Lost City, where fluid exhalation temperatures reach $92^{\circ} \mathrm{C}$ at a $\mathrm{pH}$ of $\sim 11$, provide a modern analogue (Kelley et al., 2001; Martin et al., 2008; Seyfried et al., 2015). Brucite $\left(\mathrm{Mg}[\mathrm{OH}]_{2}\right)$ is a major initial component of Lost City mounds, owing to the high concentration of $\mathrm{Mg}$ in the present-day ocean, whereas Hadean mounds would have had an iron-dominated mineralogical composition. The Hadean ocean was carbonic and rich in iron and other transition metals, so the porous precipitate mounds would have comprised amorphous to microcrystalline brucite-structured iron oxyhydroxides or green rusts $(e . g$., $\left.\sim \mathrm{Fe}^{\mathrm{II}}{ }_{4} \mathrm{Fe}^{\mathrm{III}}{ }_{2}(\mathrm{OH})_{12}\left[\mathrm{CO}_{3}\right] \cdot 3 \mathrm{H}_{2} \mathrm{O}\right)$ along with the iron sulfides mackinawite and greigite, dosed with nickel, cobalt, and molybdenum (Russell and Hall, 1997; Génin et al., 2005, 2006; Mloszewska et al., 2012; Nitschke and Russell, 2013; Russell et al., 2014; White et al., 2015; Tosca et al., 2016; Halevy et al., 2017).

Electro-geochemical gradients would have been imposed across inorganic precipitates between the mildly acidic, $\mathrm{CO}_{2}-$ rich Hadean seawater and the alkaline hydrothermal fluid laden with $\mathrm{H}_{2}$ and $\mathrm{CH}_{4}$, products of serpentinization and hydrothermal leaching, respectively (Russell et al., 1989;

\footnotetext{
${ }^{1}$ Division of Geological and Planetary Sciences, California Institute of Technology, Pasadena, California.

${ }^{2}$ LESIA, Observatoire de Paris, PSL Research University, CNRS, Sorbonne Universités, UPMC Univ. Paris 06, Univ. Paris Diderot, Sorbonne Paris Cité, Meudon, France.

${ }^{3}$ Virtual Planetary Laboratory, University of Washington, Seattle, Washington.

${ }_{5}^{4}$ Department of Astronomy, University of California Berkeley, Berkeley, California.

${ }^{5}$ Jet Propulsion Laboratory, California Institute of Technology, Pasadena, California.
} 
Table 1. Alkaline (E.G., Lost City) Versus Acidic ("Black SMoker") Hydrothermal Vents

\begin{tabular}{ll}
\hline Acidic vents & \multicolumn{1}{c}{ Alkaline vents } \\
\hline Ocean ridge & Off ridge, peridotite hosted \\
$\begin{array}{l}\text { Driven by magmatic } \\
\text { intrusion }\end{array}$ & Driven by exothermic \\
$\mathrm{T} \sim 400^{\circ} \mathrm{C}$ & $\mathrm{serpentinization}$ \\
$\mathrm{pH} \sim 3$ & $\mathrm{TH} \sim 130^{\circ} \mathrm{C}$ \\
\hline
\end{tabular}

Acidic vents are believed to be too hot and acidic for the emergence of life, but alkaline mounds offer a promising milieu for the first metabolic pathways. In addition to their innate electro-geochemical gradients imposed across their margins, submarine alkaline hydrothermal vents provide the fuels $\mathrm{H}_{2}$ and $\mathrm{CH}_{4}$, ambient electron acceptors in the form of nitrate, nitrite, and ferric iron, and a powerful suite of mineral catalysts that resemble the Fe/Ni clusters in enzymes that promote metabolism in life today (Proskurowski et al., 2006; Martin et al., 2008; Seyfried et al., 2015).

Barge et al., 2015). Nitschke and Russell (2013) suggested that the first carbon fixation pathway operated through the process of denitrifying methanotrophic acetogenesis-a putative variant of the ancient acetyl-coenzyme A pathway still used by anaerobic microbes-in which $\mathrm{H}_{2}$ reduces $\mathrm{CO}_{2}$ to $\mathrm{CO}$, and $\mathrm{CH}_{4}$ is oxidized through methanol to a methylene entity before being reduced and thiolated to give $\mathrm{CH}_{3} \mathrm{SH}$. The $\mathrm{CO}$ and $\mathrm{CH}_{3} \mathrm{SH}$ react on an iron-nickel sulfide to produce activated acetate (Huber and Wächtershäuser, 1997). Thereafter, more complex biomolecules are formed through a series of hydrogenations, carboxylations, aminations, and condensations (Huber and Wächtershäuser, 2003; Kawamura et al., 2011). The eventual waste product is acetate $\left(\mathrm{CH}_{3} \mathrm{COO}^{-}\right)$ (Russell and Martin, 2004).

However, this scheme cannot proceed unassisted; $\mathrm{CH}_{4}$ and $\mathrm{CO}_{2}$ are each notoriously unreactive molecules. The highpotential electron acceptors nitrate and/or nitrite perform two crucial roles in the earliest carbon fixation engines of life by providing the following: (1) The required extra disequilibrium to activate $\mathrm{CH}_{4}$, which is converted into methanol as nitrate/nitrite, is re-reduced to nitric oxide (NO) (Nitschke and Russell, 2013) and (2) redox bifurcate electrons by coupling the acceptance of one of two outer shell molybdenum electrons, as the other reduces the low-potential electron acceptor $\mathrm{CO}_{2}$ to $\mathrm{CO}$ (Schoepp-Cothenet et al., 2012; Nitschke and Russell, 2013; Helz et al., 2014) (Fig. 1).

In addition, nitrate and/or nitrite represent a form of fixed nitrogen that could have been reduced to ammonium for proto-biosynthesis in the otherwise inorganic membranes surrounding compartments in the Hadean hydrothermal mound. In the interlayers of green rust, carbonate, sulfide, and chloride are stable as intercalates, but nitrate and nitrite are reduced to ammonium $\left(\mathrm{NH}_{4}{ }^{+}\right)$in a matter of hours (Hansen et al., 2001; Trolard and Bourrié, 2012). Ammonium is a key ingredient for building amino acids from $\alpha$-carboxylic acids in the presence of mixed ferrous-ferric hydroxides-which are critical for turning a primitive metabolic pathway into a ligand-accelerated autocatalytic system (Huber and Wächtershäuser, 2003; Milner-White and Russell, 2008; Russell et al., 2014; White et al., 2015). For example, pyruvate, in the presence of $\mathrm{NH}_{4}{ }^{+}$, can be aminated to alanine (Huber and Wächtershäuser, 2003). Alanine could then have condensed to a 5-mer peptide on carbonate surfaces in the mound (Ka-

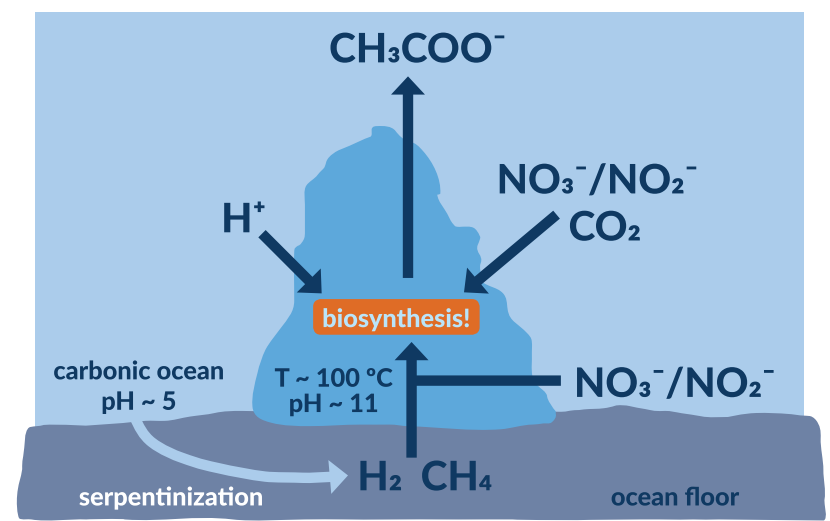

FIG. 1. The first metabolic engines would have "burned" hydrothermal fuels $\mathrm{H}_{2}$ and $\mathrm{CH}_{4}$ with the $\mathrm{NO}_{3}^{-}, \mathrm{NO}_{2}^{-}$, and $\mathrm{CO}_{2}$ found in early Earth's carbonic ocean (Branscomb and Russell, 2013; Nitschke and Russell, 2013). Nitrate and/or nitrite would be necessary to reduce $\mathrm{CO}_{2}$ to $\mathrm{CO}$ and oxidize $\mathrm{CH}_{4}$ to a methyl group. An excess of $\mathrm{H}^{+}$outside of the chimney produces a steep $\mathrm{pH}$ gradient - a natural proton motive force with the same directionality as the proton motive force driving metabolic pathways and cycles operating universally across biology to this day. Color images available online at www.liebertpub.com/ast

wamura et al., 2011). Such peptides have the potential to render iron-nickel sulfides and pyrophosphate clusters that are more stable and catalytically active, thus quickening the reactions along the pathway that had previously relied on the unadorned inorganic clusters themselves (Milner-White and Russell, 2011; Bianchi et al., 2012). Such a positive feedback would lock this cycle in as the foundation for an autocatalytic pathway at the emergence of life (e.g., Mielke et al., 2011).

Given the important role that nitrogen oxides might have played at life's emergence-both as vital high-potential electron acceptors and as the main source of fixed nitrogen to emerging biosynthesis - it behooves us to ascertain whether the production of NOx in the Hadean atmosphere would produce sufficient concentrations of nitrate and nitrite in the Hadean ocean to meet model requirements.

The Hadean, which spans the first half billion years of Earth's history, was a tumultuous time. The planet was bombarded by bolides and singed by the young Sun's intense ultraviolet radiation. Days were only $\sim 14 \mathrm{~h}$ long, massive tides were induced by a closer Moon, and continents did not exist. The ocean was twice its present volume, and the atmosphere was suffused with the products of ubiquitous volcanism (Russell et al., 2014, and references therein).

Although geochemical evidence points to an atmosphere dominated by $\mathrm{CO}_{2}$ and $\mathrm{N}_{2}$, it is still uncertain how massive the atmosphere was. Indeed, it is likely to have varied greatly during the Hadean eon under the vagaries of bolide collisions, mantle convective overturn, and accompanying tectonics. After the magma ocean phase and the condensation of ocean, the Earth's atmosphere was likely composed of around 50 bars of $\mathrm{CO}_{2}$. This pressure decreased quickly with the formation of carbonates at the seafloor. Sleep et al. (2001) estimated that the partial pressure of $\mathrm{CO}_{2}\left(\mathrm{pCO}_{2}\right)$ was 5-20 bars during the first 1-20 Myr. Afterward, $\mathrm{pCO}_{2}$ decreased to an equilibrium value that is still unknown. Ongoing work coupling global climate models (GCMs) to carbon cycling models results in a Hadean $\mathrm{pCO}_{2}$ between 0.1 and 0.5 bar, 
depending on the continental cover and the recycling in the subduction (Charnay et al., 2017).

To determine the abundance of NOx on the early Earth, we must address a wide range of atmospheric pressures. In this study, we test $\mathrm{CO}_{2}$ partial pressures of $0.1,1$, and 10 bars, complemented by 1 to 2 bars of $\mathrm{N}_{2}$.

\section{Estimates of Lightning and Lightning-Induced NO}

Along with the contribution from volcanic activity (Martin et al., 2007), lightning is the main source of nitrogen oxides (Schumann and Huntrieser, 2007) generated in the lower atmosphere. For simplicity, we ignore nitrogen fixation caused by coronal mass ejection events from the Sun (Airapetian et al., 2016). On the oxygen-rich present-day Earth, 300 moles of $\mathrm{NO}$ are generated per lightning flash (Choi et al., 2009), corresponding to a lightning-induced NO flux of $\sim 6 \times 10^{8}$ molecules $\mathrm{cm}^{-2} \mathrm{~s}^{-1}$. In the anoxic early atmosphere, electrical discharges would have heated air temperatures to tens of thousands of kelvin and incited the normally unsociable molecules $\mathrm{CO}_{2}$ and $\mathrm{N}_{2}$ to react. Electrical-discharge events shatter the robust covalent double bonds of $\mathrm{CO}_{2}$, splitting $\mathrm{CO}_{2}$ into $\mathrm{CO}$ and $\mathrm{O}$. The highly reactive $\mathrm{O}$ radical breaks $\mathrm{N}_{2}$ 's triple bond, producing $\mathrm{NO}$ and $\mathrm{N}$. The $\mathrm{N}$ radical then goes on to react with another $\mathrm{CO}_{2}$ molecule, creating $\mathrm{CO}$ and even more NO (Nna Mvondo et al., 2001; Ducluzeau et al., 2009). The process can be summarized as follows:

$$
\begin{gathered}
\mathrm{CO}_{2} \longrightarrow \mathrm{CO}+\mathrm{O}, \\
\mathrm{O}+\mathrm{N}_{2} \longrightarrow \mathrm{NO}+\mathrm{N}, \\
\mathrm{N}+\mathrm{CO}_{2} \longrightarrow \mathrm{NO}+\mathrm{CO} .
\end{gathered}
$$

This lightning-induced NO is the fundamental source of all higher-order NOx generated by photochemistry.

To estimate the amount of lightning-induced NO in the Hadean, we must first estimate the amount of lightning in the Hadean. Romps et al. (2014) derived the most accurate predictor of lightning flash rate to date:

$$
F=\frac{\eta}{E} \times P \times \mathrm{CAPE},
$$

where $F$ is the lightning flash rate per area (flashes $\mathrm{m}^{-2} \mathrm{~s}^{-1}$ ), $P$ is the precipitation rate $\left(\mathrm{kg} \mathrm{m}^{-2} \mathrm{~s}^{-1}\right)$, and CAPE is the convective available potential energy. This formula is valid in GCMs where $P$ and CAPE are derived in a cell where there is a convective cloud. We assume the constant of proportionality, $\eta / E$, which contains the efficiency $\eta$ (the ratio of power per area dissipated by lightning to the CAPE per area per time available to condensates) and the energy discharge per flash $E$ (joules), to be the same as today. We assume the present-day average lightning discharge energy $E \sim 5 \times 10^{9} \mathrm{~J} \mathrm{flash}^{-1}$. Thus,

$$
F \propto P \times \mathrm{CAPE}
$$

We run the Generic LMDZ 3D GCM to compute $P$ and CAPE for early Earth, which allows us to scale the present-day average lightning flash rate ( 1.1 flashes $\mathrm{km}^{-2}$ year $\left.{ }^{-1}\right)$ to that of an early-Earth atmosphere. The Generic LMDZ3D GCM has a universal dynamic core, a correlated-k radiative transfer code, universal turbulence and robust convection schemes in the lower atmosphere, volatile condensation in the atmosphere and surface, a 2-layer dynamic ocean, and surface and subsurface thermal balance. It has been used to great effect in studies of other planetary scenarios, including Archean Earth (Charnay et al., 2013), early Mars (Forget et al., 2013), and even terrestrial-mass exoplanets (Wordsworth et al., 2011).

The computed lightning flash rates are $0.41,9.3$, and 3.1 flashes $\mathrm{km}^{-2}$ year ${ }^{-1}$ for the 0.1-, 1-, and 10-bar $\mathrm{pCO}_{2}$ cases, respectively. An increase in the global mean surface temperature should enhance the frequency and power of convective storms and thus enhance the lightning flash rate (Romps et al., 2014). As expected, our model produces a higher lightning flash rate for the 1-bar $\mathrm{pCO}_{2}$ case (mean surface temperature of $332.8 \mathrm{~K}$ ) than for the 0.1 -bar $\mathrm{pCO}_{2}$ case $(280.4 \mathrm{~K})$. Surprisingly, the $10-$ bar $\mathrm{pCO}_{2}(388.1 \mathrm{~K})$ case has a lower flash rate than the 1-bar $\mathrm{pCO}_{2}$ case. The 10-bar $\mathrm{pCO}_{2}$ case features the warmest troposphere. Hence, the lower atmosphere is rich in water vapor, making it extremely opaque (only $7 \mathrm{~W} / \mathrm{m}^{2}$ of sunlight reaches the surface). The absorption of solar radiation in the atmosphere and a strong thermal inversion above the surface, as expected for very warm and moist climates (Pierrehumbert, 2010, p. 418), stabilize the atmosphere against moist convection. Though the precipitation rate in the 10-bar case $(5.1 \mathrm{~mm} /$ day $)$ is comparable to that of the 1-bar case $(5.8 \mathrm{~mm} /$ day $)$, there are few convective clouds and the CAPE is low, effectively suppressing the lightning flash rate by a factor of 3 .

Using empirical data for $\mathrm{NO}$ yield with respect to different $\mathrm{CO}_{2} / \mathrm{N}_{2}$ mixtures (Nna Mvondo et al., 2001) (reproduced in Fig. 2), and $E \sim 5 \times 10^{9} \mathrm{~J} \mathrm{flash}^{-1}$, we are able to calculate a lightning-induced $\mathrm{NO}$ flux for each $\mathrm{pCO}_{2}$ (Tables 2 and 3).

\section{Photochemical Production of NOx}

To evaluate the production of NOx species in the Hadean atmosphere, we adapt the 1D Caltech/JPL chemical transport model (Allen et al., 1981) to simulate the Hadean Earth.

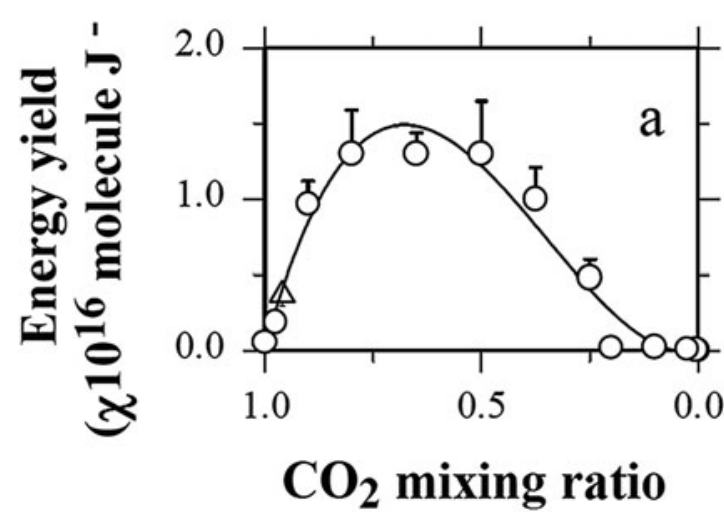

FIG. 2. A reproduction of Figure 1a from Nna Mvondo et al. (2001) showing the NO yield per J of lightning for various mixtures of $\mathrm{CO}_{2}$ and $\mathrm{N}_{2}$. The circles are Nna Mvondo's data points; the triangle is an experimental result from Venusian lightning (Levine et al., 1982) for comparison. After calculating lightning flash rates for our 0.1-, 1-, and 10-bar $\mathrm{pCO}_{2}$ cases, we use this plot to evaluate the lightning-generated NO flux in the troposphere for each case. Although we take this data as ground truth for our study, we hope that future work (either experimental or theoretical) will confirm, or otherwise, the results in this plot. 
Table 2. Additional Reactions Involving HNO and $\mathrm{HNO}_{3}$, and Their Corresponding Rate Coefficients, TO THE NAIR ET AL. (1994) MODEL

\begin{tabular}{|c|c|c|}
\hline Reaction & Rate constant $k$ & Reference \\
\hline $\begin{array}{l}\mathrm{H}+\mathrm{NO}+\mathrm{M} \longrightarrow \mathrm{HNO}+\mathrm{M} \\
\mathrm{H}+\mathrm{HNO} \longrightarrow \mathrm{H}_{2}+\mathrm{NO} \\
\mathrm{OH}+\mathrm{HNO} \longrightarrow \mathrm{H}_{2} \mathrm{O}+\mathrm{NO} \\
\mathrm{HO}_{2}+\mathrm{NO}+\mathrm{M} \longrightarrow \mathrm{HNO}_{3}+\mathrm{M}\end{array}$ & $\begin{array}{l}2.1 \times 10^{-32} e^{300 / T} \\
\quad 7 \times 10^{-12} \\
8 \times 10^{-11} e^{-500 / T} \\
3.5 \times 10^{-14} e^{250 / T}\end{array}$ & $\begin{array}{l}\text { Hampson and Garvin (1977) } \\
\text { Hampson and Garvin (1977) } \\
\text { Tsang and Herron (1991) } \\
\text { Butkovskaya et al. (2007) }\end{array}$ \\
\hline
\end{tabular}

The units for two-body and three-body reactions are $\mathrm{cm}^{3} \mathrm{~s}^{-1}$ and $\mathrm{cm}^{6} \mathrm{~s}^{-1}$, respectively.

Other versions of this model have been well tested on numerous planetary bodies, including Jupiter, Titan, and Pluto (see, e.g., Wong et al., 2015). In our early-Earth model, we simulate 28 chemical species and 156 chemical reactions. The model calculates the chemical production and loss rates at each altitude as well as the diffusive flux between each altitude grid by solving the $1 \mathrm{D}$ continuity equation:

$$
\frac{d n_{i}}{d t}=P_{i}-L_{i}-\frac{\partial \varphi_{i}}{d z}
$$

where $n_{i}$ is the number density of species $i, \varphi_{i}$ is the vertical flux, $P_{i}$ is the chemical production rate, and $L_{i}$ is the chemical loss rate, all evaluated at time $t$ and altitude $z$. The vertical flux is given by

$$
\begin{aligned}
\varphi_{i}= & -\frac{\partial n_{i}}{d z}\left(D_{i}+K_{z z}\right)-n_{i}\left(\frac{D_{i}}{H_{i}}+\frac{K_{z z}}{H_{a t m}}\right) \\
& -n_{i} \frac{\partial T}{\partial z}\left[\frac{\left(1+\alpha_{i}\right) D_{i}+K_{z z}}{T}\right]
\end{aligned}
$$

where $D_{i}$ is the species' molecular diffusion coefficient, $H_{i}$ is the species' scale height, $H_{a t m}$ is the atmospheric scale height, $\alpha_{i}$ is the thermal diffusion coefficient, $K_{z z}$ is the

Table 3. Updated Nair et al. (1994) Photolysis Rate Coefficients at the Top of the Atmosphere

\begin{tabular}{lc}
\hline Reaction & $\begin{array}{c}\text { Photolysis rate } \\
\text { coefficient at } \\
\text { 100 km }\left(\mathrm{s}^{-1}\right)\end{array}$ \\
\hline $\mathrm{O}_{2}+h v \longrightarrow \mathrm{O}+\mathrm{O}$ & $2.71 \times 10^{-6}$ \\
$\mathrm{O}_{2}+h v \longrightarrow \mathrm{O}+\mathrm{O}\left({ }^{1} \mathrm{D}\right)$ & $1.10 \times 10^{-5}$ \\
$\mathrm{O}_{3}+h v \longrightarrow \mathrm{O}_{2}+\mathrm{O}$ & $3.68 \times 10^{-4}$ \\
$\mathrm{O}_{3}+h v \longrightarrow \mathrm{O}_{2}+\mathrm{O}\left({ }^{1} \mathrm{D}\right)$ & $9.16 \times 10^{-7}$ \\
$\mathrm{H}_{2} \mathrm{O}+h v \longrightarrow \mathrm{H}+\mathrm{OH}$ & $3.03 \times 10^{-5}$ \\
$\mathrm{NO}+h v \longrightarrow \mathrm{N}+\mathrm{O}$ & $3.50 \times 10^{-6}$ \\
$\mathrm{NO}_{2}+h v \longrightarrow \mathrm{NO}+\mathrm{O}$ & $2.74 \times 10^{-3}$ \\
$\mathrm{NO}_{3}+h v \longrightarrow \mathrm{NO}+\mathrm{O}$ & $5.26 \times 10^{-2}$ \\
$\mathrm{NO}_{3}+h v \longrightarrow \mathrm{NO}+\mathrm{O}_{2}$ & $7.63 \times 10^{-3}$ \\
$\mathrm{~N}_{2} \mathrm{O}+h v \longrightarrow \mathrm{N}+\mathrm{O}\left({ }^{1} \mathrm{D}\right)$ & $1.33 \times 10^{-5}$ \\
$\mathrm{HNO}^{2}+h v \longrightarrow \mathrm{H}+\mathrm{NO}$ & $1.70 \times 10^{-3}$ \\
$\mathrm{HNO}_{2}+h v \longrightarrow \mathrm{OH}+\mathrm{NO}$ & $6.04 \times 10^{-4}$ \\
$\mathrm{HNO}_{3}+h v \longrightarrow \mathrm{OH}+\mathrm{NO}_{2}$ & $5.72 \times 10^{-5}$ \\
$\mathrm{HO}_{2} \mathrm{NO}_{2}+h v \longrightarrow \mathrm{HO}{ }_{2}+\mathrm{NO}_{2}$ & $9.59 \times 10^{-5}$ \\
$\mathrm{CO}_{2}+h v \longrightarrow \mathrm{CO}+\mathrm{O}$ & $3.31 \times 10^{-7}$ \\
$\left.\mathrm{CO}_{2}+h v \longrightarrow \mathrm{CO}+\mathrm{O}^{1} \mathrm{D}\right)$ & $5.68 \times 10^{-7}$ \\
\hline
\end{tabular}

Other than the rate coefficient for $\mathrm{HNO}+h v \longrightarrow \mathrm{H}+\mathrm{NO}$, which was taken from Kasting and Walker (1981), these rate coefficients were computed by our model from the known photochemical crosssections and the solar flux of the faint young Sun. vertical eddy diffusion coefficient, and $T$ is the temperature (Yung and DeMore, 1999).

The atmospheric temperature profiles for our photochemical runs are based on those obtained from the GCM's output. The temperature decreases with altitude, following a wet adiabat from the surface to the mesosphere, where it becomes isothermal. We calculate the eddy diffusion coefficient profile by using the formulation in the work of Ackerman and Marley (2001). Figure 3 shows the temperature and eddy diffusion coefficient profiles of all three cases.

In the lowest atmospheric level, which extends from 0 to $1.4 \mathrm{~km}$, we inject an NO flux corresponding to our calculations for lightning-induced NO production. We assume a surface $\mathrm{H}_{2}$ mixing ratio of $1 \times 10^{-3}$, corresponding to a volcanically active, weakly reduced early Earth (Kasting, 1993).

The bulk of our photochemical scheme is based on the Nair et al. (1994) model for Mars's $\mathrm{CO}_{2}-\mathrm{N}_{2}$ atmosphere, updated to include $\mathrm{HNO}$ and a new formation pathway for $\mathrm{HNO}_{3}$ (discussed later in this section). The additional reactions are listed in Table 2. Unlike the Nair et al. (1994) model, our model atmospheres are irradiated by the faint young Sun (Claire et al., 2012), and the updated photolysis rates at the top of the atmosphere $(100 \mathrm{~km})$ are calculated and catalogued in Table 3.

Our model calculates and outputs chemical abundances for each species at every level. The vertical profiles of photochemically derived $\mathrm{O}_{2}, \mathrm{NOx}$, and $\mathrm{N}_{2} \mathrm{O}$ in the 1-bar $\mathrm{pCO}_{2}$ case are presented in Figure 4.

The rainout rates for various electron acceptors are summarized in Figure 5 and Table 4. Among the NOx species, in all three cases, the flux of $\mathrm{HNO}$ rain is the highest, followed by $\mathrm{HNO}_{3}, \mathrm{HO}_{2} \mathrm{NO}_{2}$, and $\mathrm{HNO}_{2}$. Across all species, the highest rainout rate is produced in the 1-bar $\mathrm{pCO}_{2}$ case. The total amount of NOx rained out into the Hadean ocean is $2.4 \times 10^{5}, 6.5 \times 10^{8}$, and $1.9 \times 10^{8}$ molecules $\mathrm{cm}^{-2} \mathrm{~s}^{-1}$ for the $0.1-, 1-$, and 10-bar $\mathrm{pCO}_{2}$ cases, respectively.

The rainout rate of $\mathrm{H}_{2} \mathrm{O}_{2}$, another effective electron acceptor that is generated on early Earth, is quoted for comparison. In the 0.1-bar $\mathrm{pCO}_{2}$ case, $\mathrm{H}_{2} \mathrm{O}_{2}$ makes up only $2 \%$ of the electron acceptors delivered from the atmosphere to the ocean. This fraction drops to $0.02 \%$ and $0.0001 \%$ in the 1-bar and 10-bar cases, respectively, which is to be expected as the amount of $\mathrm{CO}_{2}$ increases but the surface mixing ratio of $\mathrm{H}_{2}$ remains constant. Although $\mathrm{H}_{2} \mathrm{O}_{2}$ should be considered a possible electron acceptor for early metabolisms, it was by no means the dominantly available species.

Our models reveal that $\mathrm{HNO}_{3}$ rainout is one of the primary sources of high-potential electron acceptors in the early ocean, eclipsing both $\mathrm{HNO}_{2}$ and $\mathrm{HO}_{2} \mathrm{NO}_{2}$ rainout in all three cases. The normal pathway for generating $\mathrm{HNO}_{3}$, 

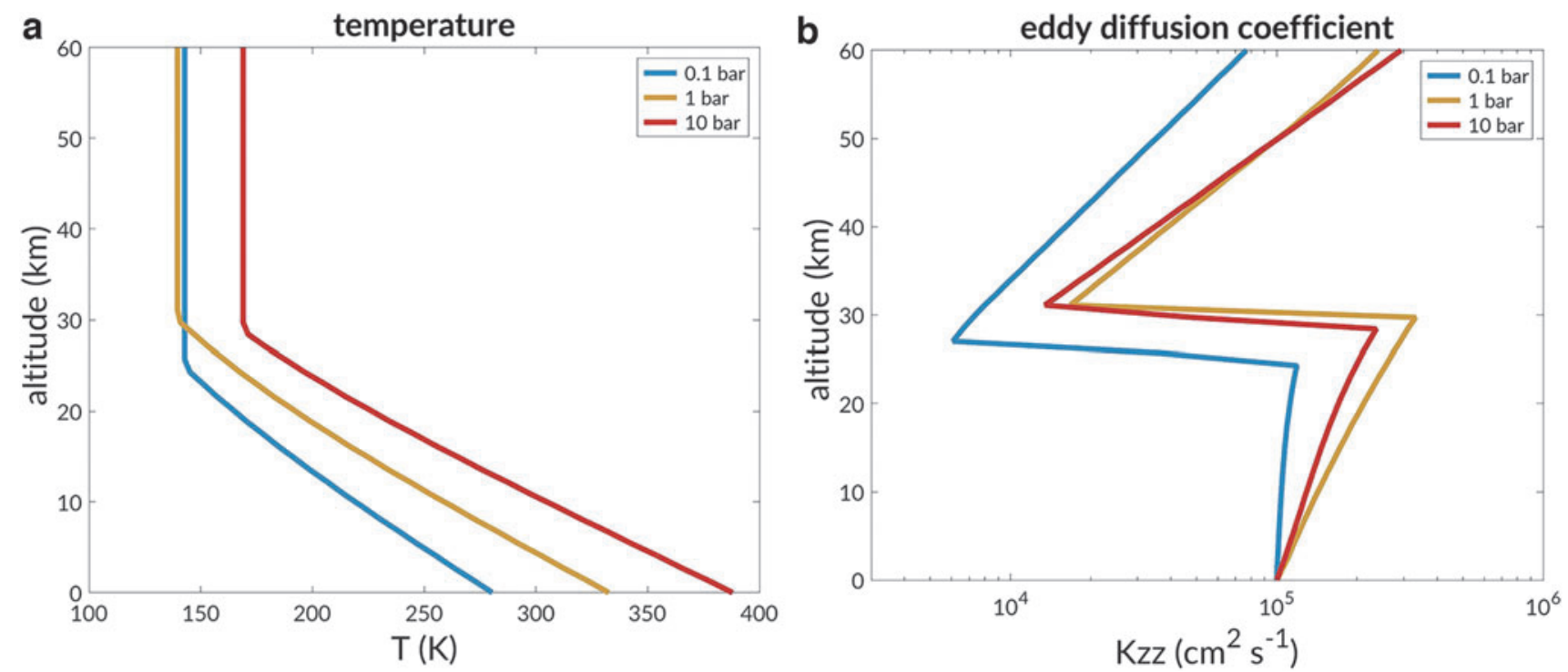

FIG. 3. (a) The atmospheric temperature profiles of the 0.1-, 1-, and 10-bar $\mathrm{pCO}_{2}$ cases. (b) The eddy diffusion coefficient profiles of the 0.1-, 1-, and 10-bar $\mathrm{pCO}_{2}$ cases, calculated by using Eq. 5 of Ackerman and Marley (2001), starting from an assumed surface value of $1 \times 10^{5} \mathrm{~cm}^{2} \mathrm{~s}^{-1}$. The inversion feature exhibited by all three cases corresponds to the location of the tropopause, as defined by the temperature profile. Color images available online at www.liebertpub.com/ast

$$
\mathrm{NO}_{2}+\mathrm{OH}+\mathrm{M} \longrightarrow \mathrm{HNO}_{3}+\mathrm{M}
$$

is stifled in the troposphere due to lack of $\mathrm{OH}$. Although $\mathrm{OH}$ is being generated by water photolysis, it is also being consumed by the reaction

$$
\mathrm{CO}+\mathrm{OH} \longrightarrow \mathrm{CO}_{2}+\mathrm{H}
$$

at high rates due to the rapid photolysis of $\mathrm{CO}_{2}$,

$$
\mathrm{CO}_{2}+h \nu \longrightarrow \mathrm{CO}+\mathrm{O} \text {. }
$$

Thus, we have included the minor channel of $\mathrm{HO}_{2}+\mathrm{NO}$ (Butkovskaya et al., 2007) in our photochemical model:

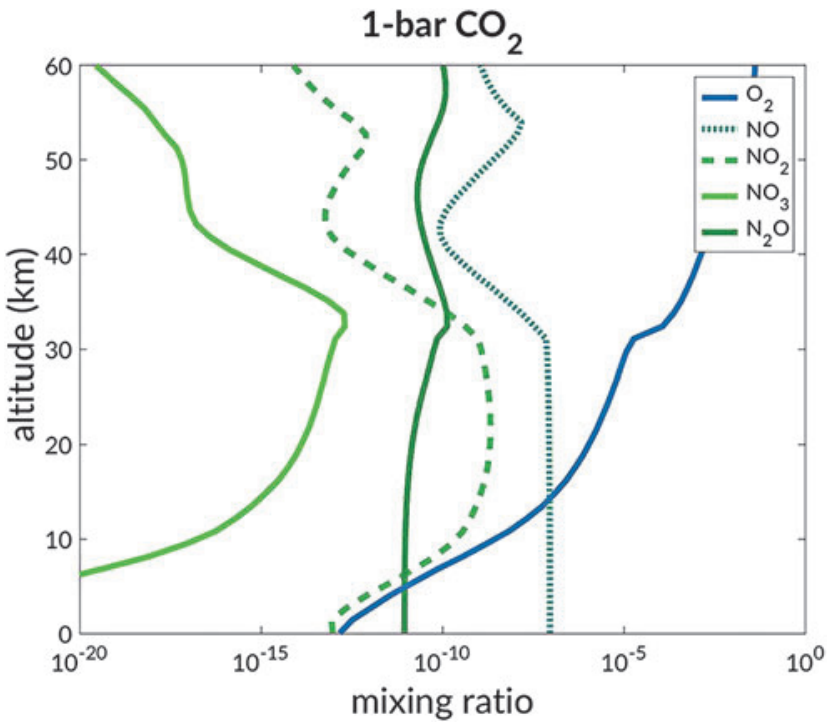

FIG. 4. The mixing ratio profiles of $\mathrm{O}_{2}, \mathrm{NOx}$, and $\mathrm{N}_{2} \mathrm{O}$ for the 1-bar $\mathrm{pCO}_{2}$ case. Color images available online at www .liebertpub.com/ast

$$
\begin{gathered}
\mathrm{HO}_{2}+\mathrm{NO} \longrightarrow \mathrm{OH}+\mathrm{NO}_{2} \text { major channel } \\
\mathrm{HO}_{2}+\mathrm{NO}+\mathrm{M} \longrightarrow \mathrm{HNO}_{3}+\mathrm{M} \text { minor channel }
\end{gathered}
$$

(R4a);

(R4b).

Though negligible when $\mathrm{OH}$ is plentiful and $\mathrm{R} 1$ is efficient, we find that this new pathway (R4b) dominates $\mathrm{HNO}_{3}$ production on early Earth.

The measurements of the rate coefficient of reaction $\mathrm{R} 4 \mathrm{~b}$ (Butkovskaya et al. 2005, 2007, 2009) have not been reproduced by other groups. In their evaluations, Sander $e t$ al. (2003) declined to make a recommendation for a preferred

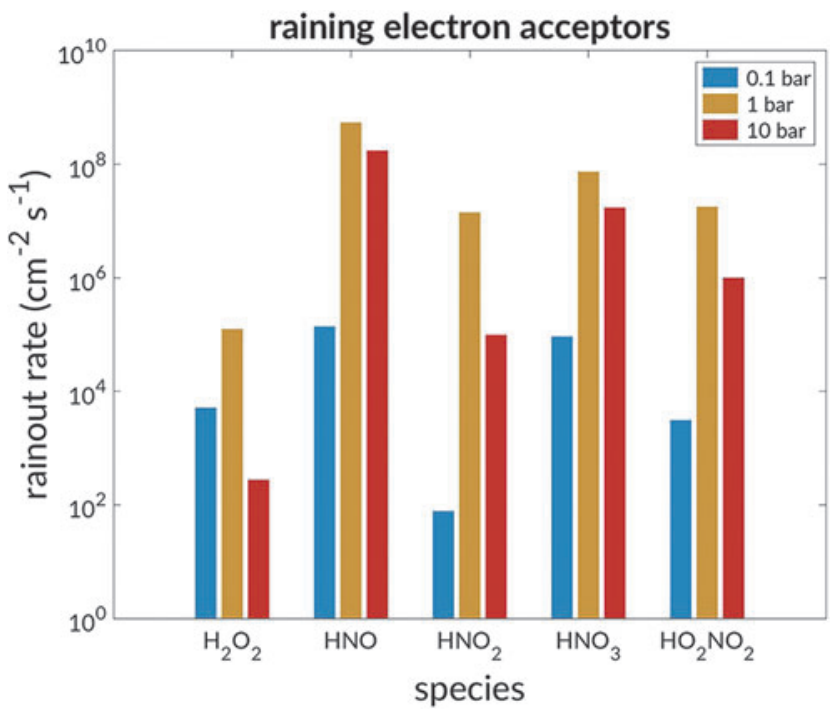

FIG. 5. The rainout rates of prospective electron acceptors for the emergence of life across all three atmospheric models. In every atmosphere tested, $\mathrm{HNO}$ is the dominant precipitate. For all species, the 1-bar $\mathrm{pCO}_{2}$ case returns the maximum rainout rate. Color images available online at www.liebertpub .com/ast 
Table 4. A Summary of the Results of the Three Cases: $0.1,1$, and 10 Bars of $\mathrm{CO}_{2}$

\begin{tabular}{|c|c|c|c|}
\hline$p \mathrm{CO}_{2}$ (bar) & 0.1 & 1 & 10 \\
\hline$T_{\text {surf }}(\mathrm{K})$ & 280.4 & 332.8 & 388.1 \\
\hline Lightning flash rate (flashes $\mathrm{km}^{-2}$ year ${ }^{-1}$ ) & 0.41 & 9.3 & 3.1 \\
\hline NO flux (molecules $\mathrm{cm}^{-2} \mathrm{~s}^{-1}$ ) & $6.5 \times 10^{6}$ & $1.7 \times 10^{9}$ & $5.6 \times 10^{8}$ \\
\hline $\mathrm{H}_{2} \mathrm{O}_{2}$ rain (molecules $\mathrm{cm}^{-2} \mathrm{~s}^{-1}$ ) & $5.1 \times 10^{3}$ & $1.3 \times 10^{5}$ & $2.8 \times 10^{2}$ \\
\hline HNO rain (molecules $\mathrm{cm}^{-2} \mathrm{~s}^{-1}$ ) & $1.4 \times 10^{5}$ & $5.5 \times 10^{8}$ & $1.8 \times 10^{8}$ \\
\hline $\mathrm{HNO}_{2}$ rain (molecules $\mathrm{cm}^{-2} \mathrm{~s}^{-1}$ ) & $7.8 \times 10^{1}$ & $1.4 \times 10^{7}$ & $9.9 \times 10^{4}$ \\
\hline $\mathrm{HNO}_{3}$ rain (molecules $\mathrm{cm}^{-2} \mathrm{~s}^{-1}$ ) & $9.3 \times 10^{4}$ & $7.4 \times 10^{7}$ & $1.7 \times 10^{7}$ \\
\hline $\mathrm{HO}_{2} \mathrm{NO}_{2}$ rain (molecules $\mathrm{cm}^{-2} \mathrm{~s}^{-1}$ ) & $3.1 \times 10^{3}$ & $1.8 \times 10^{7}$ & $1.0 \times 10^{6}$ \\
\hline Total NOx rain (molecules $\mathrm{cm}^{-2} \mathrm{~s}^{-1}$ ) & $2.4 \times 10^{5}$ & $6.5 \times 10^{8}$ & $1.9 \times 10^{8}$ \\
\hline Time (Myr) to $\mu M$ concentrations of NOx if no sinks & 48 & 0.017 & 0.058 \\
\hline $\begin{array}{l}\text { Equilibrium concentration }(\mu M) \text { of } \mathrm{NOx} \text { assuming } \\
\text { present-day hydrothermal circulation }\end{array}$ & 8.7 & $2.4 \times 10^{4}$ & $7.2 \times 10^{3}$ \\
\hline
\end{tabular}

Surface temperatures and the lightning flash rates were calculated by using the Generic LMDZ 3D global climate model for early Earth. The NO fluxes were evaluated by using data presented in Figure 2. The rainout fluxes were calculated by using the Caltech/JPL 1D photochemical model. The equilibrium concentration was calculated by using the simple box model discussed in the text and represented in Figure 6.

value. Recent experiments (Okumura, 2016, private communication) have indicated that the upper limit for the rate coefficient could be 2.5 times smaller than that reported in the previous work. Until further laboratory measurements are available, we warn that the production rate of $\mathrm{HNO}_{3}$ in our models could be overestimated by a factor of $\sim 3$.

\section{Oceanic Concentration of NOx}

After raining out, $\mathrm{HNO}$ will yield nitrate and nitrite via the following aqueous reactions (Summers and Khare, 2007):

$$
\begin{gathered}
\mathrm{HNO} \longrightarrow \mathrm{H}^{+}+\mathrm{NO}^{-} \\
\mathrm{NO}^{-}+\mathrm{NO} \longrightarrow \mathrm{N}_{2} \mathrm{O}_{2}^{-} \\
\mathrm{N}_{2} \mathrm{O}_{2}^{-}+\mathrm{NO} \longrightarrow \mathrm{N}_{3} \mathrm{O}_{3}^{-} \\
\mathrm{N}_{\mathrm{x}} \mathrm{O}_{\mathrm{x}}^{-} \longrightarrow \mathrm{NO}_{3}^{-}+\mathrm{NO}_{2}{ }^{-}+\mathrm{N}_{2} \mathrm{O}
\end{gathered}
$$

$\mathrm{HNO}_{3}$ and $\mathrm{HNO}_{2}$ simply dissociate into $\mathrm{H}^{+}$and $\mathrm{NO}_{3}{ }^{-}$or $\mathrm{NO}_{2}{ }^{-}$, respectively. $\mathrm{HO}_{2} \mathrm{NO}_{2}$ will deoxygenate rapidly, producing nitrite:

$$
\mathrm{HOONO}_{2} \longrightarrow \mathrm{HOO}^{+}+\mathrm{NO}_{2}{ }^{-} \longrightarrow \mathrm{H}^{+}+\mathrm{O}_{2}+\mathrm{NO}_{2}{ }^{-} .
$$

If the ocean reservoir has no sink for nitrate or nitrite, and assuming that every dissolved HNO molecule eventually contributes a nitrate or nitrite, it would take 48, 0.017 , and 0.058 Myr in the 0.1-, 1-, and 10-bar $\mathrm{pCO}_{2}$ cases, respectively, to build up to $\mu M$ concentrations in the Hadean ocean (taking the Hadean ocean volume to be $3 \times 10^{18} \mathrm{~m}^{3}$ in volume). The timescales for the 1- and 10-bar cases - merely blinks of an eye geologically speaking-reveal that a thick, $\mathrm{CO}_{2}$-dominated Hadean atmosphere was quite efficient at pumping nitrogen oxides into the ocean. Even the rainout in the 0.1-bar case is not insignificant. However, to better address the possibility that nitrate played an important role as an electron acceptor for denitrifying methanotrophic acetogenesis, we should consider other nitrate loss mechanisms (aside from those directly involved in this metabolic pathway), and we should solve for the equilibrium concentration of nitrate in the Hadean ocean.
$\mathrm{NO}_{3}{ }^{-}$is a primary nutrient for life in today's oceans; it is consumed as a source of nitrogen by some organisms and respired (denitrified to $\mathrm{N}_{2}$ ) by others. However, these powerful biological sinks were, of course, completely absent before the emergence of life. Instead, we must examine abiotic processes to characterize the most effective nitrate sinks.

The Hadean ocean is expected to have had dissolved $\mathrm{Fe}^{2+}$, which is known to originate at hydrothermal systems, and which can be oxidized to $\mathrm{Fe}^{3+}$. However, we consider $\mathrm{Fe}^{2+}$ to be inefficient at reducing nitrate or nitrite, because on presentday Earth, where there is an abundance of nitrate and nitrite, dissolved ferrous iron is able to traverse thousands of kilometers from its origin at hydrothermal vent sites to scientific sampling stations without trouble (Fitzsimmons et al., 2014).

Summers (2005) showed experimentally that FeS suspensions can reduce nitrite to ammonium in Hadean ocean environments. Nitrate can also be reduced to ammonium, but at a significantly lower yield. Summers (2005) could not reduce nitrate to ammonium at $\mathrm{pH}>6.9$, indicating that nitrate is probably not reduced by iron sulfide in great amounts by this process at alkaline hydrothermal vents. Further, nitrate is not readily reduced to ammonium in the presence of other species such as $\mathrm{Cl}^{-}$and $\mathrm{SO}_{4}{ }^{-2}$. We expect such anions to be dissolved in the Hadean ocean, making nitrate reduction by $\mathrm{FeS}$ insignificant.

Aqueous photochemistry at the ocean surface is capable of converting nitrate into nitrite and vice versa (Mack and Bolton, 1999), but because both species can serve as electron acceptors, this would not present a problem for the emergence of life. Because this photochemistry only affects a tiny fraction of the ocean, the nitrate lost to nitrite in this manner, which can then be reduced by $\mathrm{FeS}$, is negligible in the present context.

Thus, we consider the dominant NOx loss mechanism to be extreme heating $\left(\sim 400^{\circ} \mathrm{C}\right)$ as ocean water cycles through acidic hydrothermal vents. At such high temperatures, nitrate and nitrite would be reduced back to $\mathrm{N}_{2}$ by iron minerals within the crust. There may also be some reduction of nitrate in the water cycling by moderate-temperature, serpentinizationdriven alkaline springs, though the product in this case is likely to be ammonia, thus merely adding to that entity at alkaline vents (Gordon et al., 2013). 


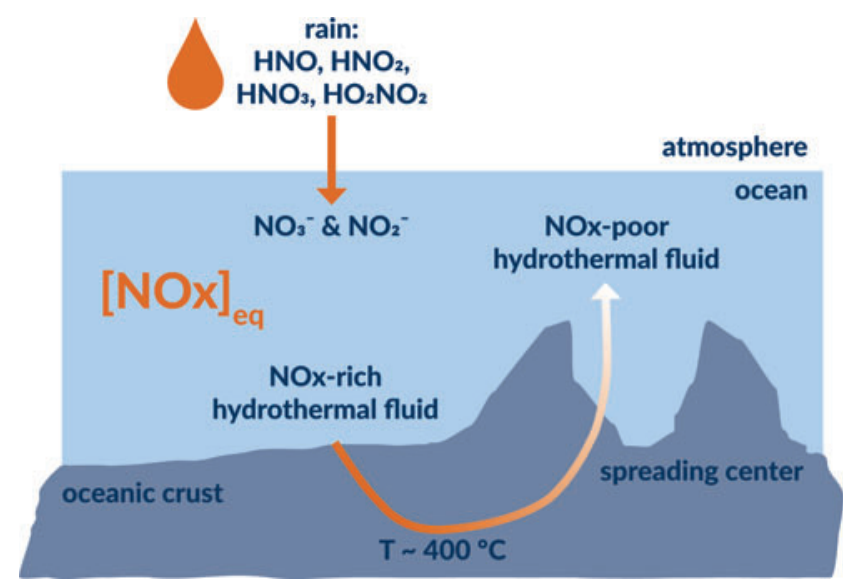

FIG. 6. A simple box model for calculating the equilibrium concentration of nitrate and nitrite in the Hadean ocean. We assume that the primary source is acid rain from the atmosphere and that the dominant sink is removal by extreme heating at high-temperature hydrothermal sites. Color images available online at www.liebertpub.com/ast

We construct a simple box model to ascertain the equilibrium nitrate concentration (Fig. 6). Assuming 100\% destruction of NOx at black-smoker temperatures, the equilibrium number concentration of NOx is

$$
C_{\mathrm{NOx}}=\frac{f_{\mathrm{atm}} A_{\oplus} \tau_{\mathrm{HTV}}}{V_{\text {ocean }}},
$$

where $f_{\text {atm }}$ is the NOx flux from the atmosphere (molecules $\left.\mathrm{cm}^{-2} \mathrm{~s}^{-1}\right), A_{\oplus}$ is the surface area of the Earth $\left(5.1 \times 10^{18} \mathrm{~cm}^{2}\right)$, $\tau_{\mathrm{HTV}}$ is the timescale for cycling through high-temperature vents, and $V_{\text {ocean }}$ is the volume of the Hadean ocean $\left(\sim 3 \times 10^{18}\right.$ $\mathrm{m}^{3}$ ). Because $\tau_{\mathrm{HTV}}=V_{\text {ocean }} / F_{\mathrm{HTV}}$, where $F_{\mathrm{HTV}}$ is the mass flux of water through high-temperature hydrothermal vents,

$$
C_{\mathrm{NOx}}=\frac{f_{\mathrm{atm}} A_{\oplus}}{F_{\mathrm{HTV}}} .
$$

According to Nielsen et al. (2006), the current water mass flux from high-temperature vents is $7.2 \times 10^{12} \mathrm{~kg} \mathrm{year}^{-1}$. Using this present-day value and $f_{\text {atm }} \sim 6.5 \times 10^{8}$ molecules $\mathrm{cm}^{-2} \mathrm{~s}^{-1}$ (as in the 1-bar case), then $C_{\mathrm{NOx}}=24 \mathrm{~m} M$. Acidic vents were more prevalent in the Hadean, though by what degree is still unknown. However, unless the water flux through high-temperature vents was thousands of times as great as today, the equilibrium nitrate concentration would still exceed $1 \mu M$.

\section{Conclusion}

NOx are believed to be needed as high-potential electron acceptors for the emergence of metabolism at submarine alkaline hydrothermal vents. NOx are created in early Earth's $\mathrm{CO}_{2}-\mathrm{N}_{2}$ atmosphere, but the atmospheric pressure during the Hadean is uncertain and likely varied widely. We have demonstrated, using atmospheric models supported by data, that there was a prevalence of NOx produced in the Hadean atmosphere for a large range of $\mathrm{pCO}_{2}$. This $\mathrm{NOx}$ rained out into the Hadean ocean primarily as $\mathrm{HNO}$, which reacted to form nitrate and nitrite in solution. Although the 10-bar $\mathrm{pCO}_{2}$ case probably only applies to the first few 10 s Myr of Earth's history, it still produced significant amounts of NOx. As the $\mathrm{pCO}_{2}$ settled around the 0.1-1 bar for the long term, copious NOx was also being delivered to the Hadean ocean. If the water flux through high-temperature hydrothermal vents was not more than thousands of times what it is today, the steadystate nitrate concentration would be micromolar, supplying onsite electron acceptors and a potential amino source at the emergence of life.

\section{Acknowledgments}

This research was supported in part by an NAI Virtual Planetary Laboratory grant from the University of Washington to the Jet Propulsion Laboratory and California Institute of Technology. B.D.C. acknowledges support from an appointment to the NASA Postdoctoral Program, administered by Universities Space Research Association. M.J.R.'s research was supported by the National Aeronautics and Space Administration, through the NASA Astrobiology Institute under cooperative agreement issued through the Science Mission directorate; No. NNH13ZDA017C (Icy Worlds) at the Jet Propulsion Laboratory.

\section{Author Disclosure Statement}

No competing financial interests exist.

\section{References}

Ackerman, A.S. and Marley, M.S. (2001) Precipitating condensation clouds in substellar atmospheres. Astrophys $J$ 556:872-884.

Airapetian, V.S., Glocer, A., Gronoff, G., Hébrard, E., and Danchi, W. (2016) Prebiotic chemistry and atmospheric warming of early Earth by an active young Sun. Nat Geosci 9:452-455.

Allen, M., Yung, Y.L., and Waters, J.W. (1981) Vertical transport and photochemistry in the terrestrial mesosphere and lower thermosphere (50-120 km). J Geophys Res 86:3617-3627.

Barge, L.M., Abedian, Y., Russell, M.J., Doloboff, I.J., Cartwright, J.H.E., Kidd, R.D., and Kanik, I. (2015) From chemical gardens to fuel cells: generation of electrical potential and current across self-assembling iron mineral membranes. Angew Chem Int Ed 54:8184-8187.

Bianchi, A., Giorgi, C., Ruzza, P., Toniolo, C., and Milner-White, E.J. (2012) A synthetic hexapeptide designed to resemble a proteinaceous p-loop nest is shown to bind inorganic phosphate. Proteins 80:1418-1424.

Branscomb, E. and Russell, M.J. (2013) Turnstiles and bifurcators: the disequilibrium converting engines that put metabolism on the road. Biochim Biophys Acta 1827:62-78.

Butkovskaya, N., Kukui, A., Pouvesle, N., and Le Bras, G. (2005) Formation of nitric acid in the gas-phase $\mathrm{HO}_{2}+\mathrm{NO}$ reaction: effects of temperature and water vapor. $J$ Phys Chem A 109:6509-6520.

Butkovskaya, N., Kukui, A., Bras, G.L. (2007) $\mathrm{HNO}_{3}$ forming channel of the $\mathrm{HO}_{2}+\mathrm{NO}$ reaction as a function of pressure and temperature in the ranges of 72-600 Torr and 223-323 K. J Phys Chem A 111:9047-9053.

Butkovskaya, N., Rayez, M.T., Rayez, J.-C., Kukui, A., and Le Bras, G. (2009) Water vapor effect on the $\mathrm{HNO}_{3}$ yield in the $\mathrm{HO}_{2}+\mathrm{NO}$ reaction: experimental and theoretical evidence. J Phys Chem A 113:11327-11342. 
Charnay, B., Forget, F., Wordsworth, R., Leconte, J., Millour, E., Codron, F., and Spiga, A. (2013) Exploring the faint young Sun problem and the possible climates of the Archean Earth with a 3-D GCM. J Geophys Res Atmos 118:1041410431.

Charnay, B., Le Hir, G., Fluteau, F., Forget, F., and Catling, D.-C. (2017) A warm or a cold early Earth? New insights from a 3-D climate-carbon model. Earth Planet Sci Lett 474:97-109.

Choi, Y., Kim, J., Eidering, A., Osterman, G., Yung, Y.L., Gu, Y., and Liou, K.N. (2009) Lightning and anthropogenic NOx sources over the United States and the western North Atlantic Ocean: impact on OLR and radiative effects. Geophys Res Lett 36:1-5.

Claire, M.W., Sheets, J., Cohen, M., Ribas, I., Meadows, V.S., and Catling, D.C. (2012) The evolution of solar flux from $0.1 \mathrm{~nm}$ to $160 \mu \mathrm{m}$ : quantitative estimates for planetary studies. Astrophys J 757:95.

Ducluzeau, A.L., van Lis, R., Duval, S., Schoepp-Cothenet, B., Russell, M.J., and Nitschke, W. (2009) Was nitric oxide the first deep electron sink? Trends Biochem Sci 34:9-15.

Fitzsimmons, J.N., Boyle, E.A., and Jenkins, W.J. (2014) Distal transport of dissolved hydrothermal iron in the deep South Pacific Ocean. Proc Natl Acad Sci U S A 111:16654-16661.

Forget, F., Wordsworth, R., Millour, E., Madeleine, J.B., Kerber, L., Leconte, J., Marcq, E., and Haberle, R.M. (2013) 3D modelling of the early martian climate under a denser $\mathrm{CO}_{2}$ atmosphere: temperatures and $\mathrm{CO}_{2}$ ice clouds. Icarus 222:81-99.

Génin, J.M.R., Abdelmoula, M., Aïssa, R., and Ruby, C. (2005) Ordering in FeII-III hydroxysalt green rusts from XRD and Mössbauer analysis (chloride, carbonate, sulphate, oxalate...); about the structure of hydrotalcite-like compounds. Hyperfine Interact 166:391-396.

Génin, J.M.R., Ruby, C., Géhin, A., and Refait, P. (2006) Synthesis of green rusts by oxidation of $\mathrm{Fe}(\mathrm{OH})_{2}$, their products of oxidation and reduction of ferric oxyhydroxides; Eh-pH Pourbaix diagrams. Comptes Rendus Geosci 338:433-446.

Gordon, A.D., Smirnov, A., Shumlas, S.L., Singireddy, S., DeCesare, M., Schoonen, M.A.A., and Strongin, D.R. (2013) Reduction of nitrite and nitrate on nano-dimensioned FeS. Orig Life Evol Biosph 43:305-322.

Halevy, I., Alesker, M., Schuster, E.M., Popovitz-Biro, R., and Feldman, Y. (2017) A key role for green rust in the Precambrian oceans and the genesis of iron formations. Nat Geosci 10:135-139.

Hampson, R.F.J. and Garvin, D. (1977) Reaction rate and photochemical data for atmospheric chemistry-1977. Natl Bur Stand Spec Publ 513:36;47.

Hansen, H.C.B., Guldberg, S., Erbs, M., and Koch, C.B. (2001) Kinetics of nitrate reduction by green rusts-effects of interlayer anion and Fe(II):Fe(III) ratio. Appl Clay Sci 18:81-91.

Helz, G.R., Erickson, B.E., and Vorlicek, T.P. (2014) Stabilities of thiomolybdate complexes of iron; implications for retention of essential trace elements $(\mathrm{Fe}, \mathrm{Cu}, \mathrm{Mo})$ in sulfidic waters. Metallomics 6:1131-1140.

Huber, C. and Wächtershäuser, G. (1997) Activated acetic acid by carbon fixation on (Fe, Ni) $\mathrm{S}$ under primordial conditions. Science 276:245-247.

Huber, C. and Wächtershäuser, G. (2003) Primordial reductive amination revisited. Tetrahedron Lett 44:1695-1697.

Kasting, J.F. (1993) Earth's early atmosphere. Science 259, 920-926.
Kasting, J.F., and Walker, J.C.G. (1981) Limits on oxygen concentration in the prebiological atmosphere and the rate of abiotic fixation of nitrogen. J Geophys Res 86:1147.

Kawamura, K., Takeya, H., Kushibe, T., and Koizumi, Y. (2011) Mineral-enhanced hydrothermal oligopeptide formation at the second time scale. Astrobiology 11:461-469.

Kelley, D.S., Karson, J.A., Blackman, D.K., Früh-Green, G.L., Butterfield, D.A., Lilley, M.D., Olson, E.J., Schrenk, M.O., Roe, K.K., Lebon, G.T., and Rivizzigno, P. (2001) An offaxis hydrothermal vent field near the Mid-Atlantic Ridge at 30 degrees N. Nature 412:145-149.

Levine, J.S., Gregory, G.L., Harvey, G.A., Howell, W.E., Borucki, W.J., and Orville, R.E. (1982) Production of nitric oxide by lightning on Venus. Geophys Res Lett 9:893-896.

Mack, J., and Bolton, J.R. (1999) Photochemistry of nitrite and nitrate in aqueous solution: a review. J Photochem Photobiol A Chem 128:1-13.

Mancinelli, R.L., and McKay, C.P. (1988) The evolution of nitrogen cycling. Orig Life Evol Biosph 18:311-325.

Martin, R.S., Mather, T.a., and Pyle, D.M. (2007) Volcanic emissions and the early Earth atmosphere. Geochim Cosmochim Acta 71:3673-3685.

Martin, W., Baross, J., Kelley, D., and Russell, M.J. (2008) Hydrothermal vents and the origin of life. Nat Rev Microbiol 6:805-814.

Mielke, R.E., Robinson, K.J., White, L.M., McGlynn, S.E., McEachern, K., Bhartia, R., Kanik, I., and Russell, M.J. (2011) Iron-sulfide-bearing chimneys as potential catalytic energy traps at life's emergence. Astrobiology 11:933-950.

Milner-White, E.J. and Russell, M.J. (2008) Predicting the conformations of peptides and proteins in early evolution. A review article submitted to Biology Direct. Biol Direct 3:3.

Milner-White, E.J. and Russell, M.J. (2011) Functional capabilities of the earliest peptides and the emergence of life. Genes (Basel) 2:671-688.

Mloszewska, A.M., Pecoits, E., Cates, N.L., Mojzsis, S.J., O'Neil, J., Robbins, L.J., and Konhauser, K.O. (2012) The composition of Earth's oldest iron formations: the Nuvvuagittuq Supracrustal Belt (Québec, Canada). Earth Planet Sci Lett 317-318:331-342.

Nair, H., Allen, M., Anbar, A.D., Yung, Y.L., and Clancy, R.T. (1994) A photochemical model of the Martian atmosphere. Icarus 111:124-150.

Nielsen, S.G., Rehkämper, M., Teagle, D.A.H., Butterfield, D.A., Alt, J.C., and Halliday, A.N. (2006) Hydrothermal fluid fluxes calculated from the isotopic mass balance of thallium in the ocean crust. Earth Planet Sci Lett 251:120-133.

Nitschke, W., and Russell, M.J. (2013) Beating the acetyl coenzyme A-pathway to the origin of life. Philos Trans $R$ Soc Lond B Biol Sci 368:20120258.

Nna Mvondo, D., Navarro-Gonzalez, R., McKay, C.P., Coll, P., and Raulin, F. (2001) Production of nitrogen oxides by lightning and coronae discharges in simulated early Earth, Venus and Mars environments. Adv Space Res 27:217-223.

Pierrehumbert, R.T. (2010) Principles of Planetary Climates. Cambridge University Press, Cambridge.

Proskurowski, G., Lilley, M.D., Kelley, D.S., and Olson, E.J. (2006) Low temperature volatile production at the Lost City Hydrothermal Field, evidence from a hydrogen stable isotope geothermometer. Chem Geol 229:331-343.

Romps, D.M., Seeley, J.T., Vollaro, D., and Molinari, J. (2014) Projected increase in lightning strikes in the United States due to global warming. Science 346:851-854. 
Russell, M.J. and Hall, A.J. (1997) The emergence of life from iron monosulphide bubbles at a submarine hydrothermal redox and pH front. J Geol Soc London 154:377-402.

Russell, M.J. and Martin, W. (2004) The rocky roots of the acetyl-CoA pathway. Trends Biochem Sci 29:358-363.

Russell, M.J., Hall, A.J., and Turner, D. (1989) In vitro growth of iron sulphide chimneys: possible culture chambers for origin-of-life experiments. Terra Nova 1:228-241.

Russell, M.J., Hall, A.J., and Martin, W. (2010) Serpentinization as a source of energy at the origin of life. Geobiology 8:355-371.

Russell, M.J., Barge, L.M., Bhartia, R., Bocanegra, D., Bracher, P.J., Branscomb, E., Kidd, R., McGlynn, S., Meier, D.H., Nitschke, W., Shibuya, T., Vance, S., White, L., and Kanik, I. (2014) The drive to life on wet and icy worlds. Astrobiology 14:308-343.

Sander, S.P., Ravishankara, A.R., Golden, D.M., Kolb, C.E., Kurylo, M.J., Molina, M.J., Moortgat, G.K., and FinlaysonPitts, B.J. (2003) Chemical Kinetics and Photochemical Data for Use in Atmospheric Studies: evaluation number 14. JPL Publ 02-25 14:1-334.

Schoepp-Cothenet, B., van Lis, R., Philippot, P., Magalon, A., Russell, M.J., and Nitschke, W. (2012) The ineluctable requirement for the trans-iron elements molybdenum and/or tungsten in the origin of life. Sci Rep 2:1-5.

Schumann, U. and Huntrieser, H. (2007) The global lightninginduced nitrogen oxides source. Atmos Chem Phys Discuss 7:2623-2818.

Seyfried, W.E., Pester, N.J., Tutolo, B.M., and Ding, K. (2015) The Lost City hydrothermal system: constraints imposed by vent fluid chemistry and reaction path models on subseafloor heat and mass transfer processes. Geochim Cosmochim Acta 163:59-79.

Shibuya, T., Russell, M.J., and Takai, K. (2016) Free energy distribution and hydrothermal mineral precipitation in Hadean submarine alkaline vent systems: importance of iron redox reactions under anoxic conditions. Geochim Cosmochim Acta 175:1-19.

Sleep, N.H., Zahnle, K., and Neuhoff, P.S. (2001) Initiation of clement surface conditions on the earliest Earth. Proc Natl Acad Sci U S A 98:3666-3672.

Summers, D.P. (2005) Ammonia formation by the reduction of nitrite/nitrate by FeS: ammonia formation under acidic conditions. Orig Life Evol Biosph 35:299-312.

Summers, D.P. and Khare, B. (2007) Nitrogen fixation on early Mars and other terrestrial planets: experimental demonstra- tion of abiotic fixation reactions to nitrite and nitrate. Astrobiology 7:333-341.

Tosca, N.J., Guggenheim, S., and Pufahl, P.K. (2016) An authigenic origin for Precambrian greenalite: implications for iron formation and the chemistry of ancient seawater. Geol Soc Am Bull 128:511-530.

Trolard, F. and Bourrié, G. (2012) Fougerite a natural layered double hydroxide in gley soil: habitus, structure, and some properties. In Clay Minerals in Nature: Their Characterization, Modification and Application, edited by M. Valaskova and G.S. Martynkova; InTech, Rijeka, Croatia, pp 171-188.

Tsang, W. and Herron, J.T. (1991) Chemical kinetic data base for propellant combustion I. Reactions involving $\mathrm{NO}, \mathrm{NO}_{2}$, $\mathrm{HNO}, \mathrm{HNO}_{2}, \mathrm{HCN}$ and $\mathrm{N}_{2}$ O. J. Phys Chem Ref Data 20: 609-663.

White, L.M., Bhartia, R., Stucky, G.D., Kanik, I., and Russell, M.J. (2015) Mackinawite and greigite in ancient alkaline hydrothermal chimneys: identifying potential key catalysts for emergent life. Earth Planet Sci Lett 430:105-114.

Wong, M.L., Yung, Y.L., and Gladstone, G.R. (2015) Pluto's implications for a Snowball Titan. Icarus 246: 192-196.

Wordsworth, R.D., Forget, F., Selsis, F., Millour, E., Charnay, B., and Madeleine, J.-B. (2011) Gliese 581D is the first discovered terrestrial-mass exoplanet in the habitable zone. Astrophys $J$ 733:L48.

Address correspondence to: Michael L. Wong Division of Geological and Planetary Sciences California Institute of Technology Mail Code 150-21 Pasadena, CA 91125

E-mail: tinkertenordoctorspy@gmail.com

Submitted 25 January 2016 Accepted 22 March 2017
Abbreviations Used
GCM $=$ global climate models $\mathrm{NOx}=$ nitrogen oxide 